Article

\title{
Optimization of Thermo-Alkali Stable Amylase Production and Biomass Yield from Bacillus sp. Under Submerged Cultivation
}

\author{
Ameer Khusro, Kaliyan Barathikannan, Chirom Aarti and Paul Agastian* \\ Research Department of Plant Biology and Biotechnology, Loyola College, Nungambakkam, \\ Chennai 600034, Tamil Nadu, India; armankhan0301@gmail.com (A.K.); \\ bharathikannan1210@gmail.com (K.B.); aartichirom@gmail.com (C.A.) \\ * Correspondence: agastianloyolacollege@gmail.com or agastian@loyolacollege.edu; \\ Tel.: +91-94-4443-3117; Fax: +91-44-2817-5566
}

Academic Editors: Yanna Liang and Badal C. Saha

Received: 28 October 2016; Accepted: 20 January 2017; Published: 4 February 2017

\begin{abstract}
The present context was investigated to optimize amylase production and cell biomass of poultry-associated Bacillus sp. using a conventional as well as statistical approach. Box-Behnken design (BBD) matrix at $N=29$ was employed to optimize four independent variables, selected from one factor at a time (OFAT) technique, for maximum amylase production and biomass yield. The relative activity of crude amylase obtained from the isolate showed stability at high temperature $\left(60^{\circ} \mathrm{C}\right)$ and alkaline condition ( $\mathrm{pH} 9$ ) up to $4 \mathrm{~h}$ of incubation, thereby indicating its alkali-tolerant and thermo-stable property. The BBD resulted in enhanced amylase activity of $145.32 \mathrm{U} / \mathrm{mL}$ when the basal medium was slightly acidic ( $\mathrm{pH}$ 6) and kept at a temperature of $35^{\circ} \mathrm{C}$ with the shaking speed of $130 \mathrm{rpm}$, in addition to being incubated for $24 \mathrm{~h}$. The selected factors, when employed with this statistical optimization approach, showed 1.5-fold and 2-fold enhancements in the amylase production and biomass yield respectively compared to the OFAT method. Analysis of variance (ANOVA) revealed high coefficient of determination $\left(R^{2}\right)$ of 0.96 to 0.99 for both the responses at significant level $(p<0.05)$. Three-dimensional response and 2D contour plot of the quadratic model showed interdependent interaction between the effective variables. Long-term thermo-alkali stability of amylase obtained from Bacillus sp. suggested not only its wide applications in pharmaceutical, food and biotechnological industries, but also suggested a potent replacement of existing amylases on the market.
\end{abstract}

Keywords: amylase; Bacillus sp.; Box-Behnken design; one factor at a time; poultry farm

\section{Introduction}

Amylases constitute a group of enzymes that yields dextrin and numerous monomer products by hydrolysing $\alpha-1,4$ glycosidic linkages of starch molecules. These amylolytic enzymes are of great significance in many biotechnological processes including pharmaceutical, food, textile, fibre, detergent, brewing, oil drilling and paper industries [1]. Plants, animals, bacteria and fungi are the dormant sources of amylases. Amylase (EC 3.2.1.1) production from microbial sources have gained immense interest among researchers because of bulk production capability and the easy manipulation of the microorganisms in order to produce enzymes with the desired characteristics [2]. Moreover, bacterial amylases have a broad application in industries due to their stability, high enzyme activity at various parameters and cost-effective production. Members of the genus Bacillus are well-known producers of a large variety of extracellular enzymes, of which amylases play a critical role at the industrial scale. Bacillus sp. is an industrial microorganism that has been exploited commercially due to short fermentation cycle, consistency, safe handling, eco-friendly characteristics, easy manipulation, enhanced enzymatic activity at harsh conditions, cost-effective enzyme production and ability to secrete secondary 
metabolites extracellularly into the medium [3]. Despite the similar growth profile of different Bacillus sp., the production of amylases from Bacillus sp. is dependent upon the medium components, physical parameters and the type of strain. There is an obligation to enhance the production of amylase due to its wider applications in various biotechnological areas. The production of enzymes can be enhanced by optimizing the medium constituents along with the other important parameters.

Recent studies have focused on the process development and scale up of amylase production by optimizing the factors required for the bacterial growth in submerged fermentation (SmF). SmF is preferred commonly to solid state fermentation (SSF) while cultivating bacteria for enzyme production due to easy purification of the products obtained. In general, the production of amylase by SmF shows ease of sterilization and process managements. Additionally, SmF utilizes free-flowing liquid substrates, and the bioactive components are secreted into the fermentation medium. The SmF supports the utilization of substrates rapidly and this fermentation system is usually implemented in case of enzyme production from diverse bacteria, due to the requirement of higher water potential. Most importantly, SmF supports the utilization of genetically modified organisms to a greater extent than SSF due to controlled physical factors. Recently, few studies supported the successful utilization of $\mathrm{SmF}$ in order to produce amylase from Bacillus sp. in a cost-effective approach $[4,5]$.

Process optimization by the "one factor at a time" (OFAT) technique is not only time consuming but also can cause misinterpretation of data due to the large number of experiments needing to be carried out. The limitations of the OFAT technique can be eliminated by using response surface methodology (RSM). RSM is a mathematical model which is used to optimize the fermentation process for improving the enzyme yield by combining all the factors involved in the experimental analysis [6,7]. RSM deals with the experimental strategies, model developing and statistical methods for constructing a relationship between a response and the design variables. In fact, the incorporation of RSM into optimization studies reduces the number of experiments and establishes a model, illustrating the influence of dependent as well as independent variables and their respective mutual interactions on the various responses. Since the rate of enzyme production varies with each bacterial strain, it is essential to develop a statistical model for the optimization of the fermentation process involved in the enhanced amylase production. In the last few years, Bacillus sp. such as B. subtilis, B. licheniformis, B. amyloliquefaciens, B. polymyxa, B. megaterium etc. had already been studied as potent producers of amylase [8]. However, there are still limited research activities on the production of thermo-alkali stable amylase from Bacillus sp. The growing demands of amylase for biotechnological applications show an urgency to produce the enzyme at a large scale with reduced cost and time [9].

Keeping in view the broad-spectrum applications and substantial necessity of thermo-alkali-tolerant amylase at the industrial scale, especially in food industries, the present study was carried out to enhance the production of amylase from Bacillus sp. with optimum conditions using RSM. BBD, based on three levels, was selected to study the effect of four influential variables- $\mathrm{pH}$, temperature, agitation rate and incubation time- on the responses.

\section{Materials and Methods}

\subsection{Sample Collection and Isolation of Amylolytic Strain}

Poultry feces soil sample was collected from a poultry farm in Guduvanchery, Tamil Nadu, India. The sample was brought to the laboratory in a sterile condition and the hyperamylolytic bacterium was isolated on starch agar media (g/L: Starch 10.0, Agar 20.0 and $\mathrm{pH} 7.0$ ) using the spread plate technique. The isolated culture was streaked on starch agar plate for qualitative assay of amylase production. The culture was maintained in $20 \%$ glycerol at $-80^{\circ} \mathrm{C}$ for further use.

\subsection{Identification and Molecular Characterization of Bacteria}

The standard Bergey's Manual of Systemic Bacteriology was used for the identification (morphological and biochemical properties) of potent isolate [10]. Genomic DNA of bacteria was isolated 
and the amplicon was obtained using the thermal cycler (Eppendorf Gradient, Chennai, India) and universal primers. The amplicon was purified and the sequencing was carried out using an automated sequencer (Genetic Analyzer 3130, Applied Biosystems, Foster city, CA, USA). The similarity search of the sequence was performed using the NCBI, BLAST and the sequence was submitted to GenBank for assigning accession number of the strain. Phylogenetic tree of the isolate with closest Bacillus species were constructed using MEGA (Molecular Evolution Genetic Analysis) software version 4.

\subsection{Inoculum Preparation}

Nutrient broth $(50 \mathrm{~mL}, \mathrm{pH}-7.0)$ was prepared in a conical flask with volumetric capacity of $250 \mathrm{~mL}$. The broth was kept for cooling after sterilization. A loopful of bacteria was inoculated aseptically into the medium under sterile conditions. Further, the culture was incubated overnight at $37^{\circ} \mathrm{C}$ with agitation speed of $130 \mathrm{rpm}$.

\subsection{Submerged Fermentation}

The bacterial inoculums $(500 \mu \mathrm{L})$ were inoculated into $50 \mathrm{~mL}$ of culture medium. The fermentation medium consisted of: [ $(w / v) 0.6 \%$ peptone; $0.05 \% \mathrm{MgSO}_{4} ; 0.05 \% \mathrm{KCl} ; 1 \%$ starch; $\left.\mathrm{pH} 7.0\right]$. The culture was kept at $37{ }^{\circ} \mathrm{C}$ with agitation speed of $130 \mathrm{rpm}$ and further centrifuged at $8000 \times g$ for 15 min after overnight incubation for collecting the supernatant. The quantitative estimation for amylase yield was assayed based on the standard procedure by using the bacterial supernatant.

\subsection{Enzyme Assay and Biomass Determination}

Amylase activity was estimated following the methodology of Miller [11] with minor modifications. The supernatant of overnight grown bacterial culture was used as crude enzyme. One milliliter of supernatant was mixed with $1 \mathrm{~mL}$ of solubilized starch solution $(1 \% w / v)$ and the reaction mixture was incubated in a tube at $60{ }^{\circ} \mathrm{C}$ for $10 \mathrm{~min}$. The reaction was stopped by adding $1 \mathrm{~mL}$ of dinitrosalicylic acid (DNS) into it and the solution was incubated at $100{ }^{\circ} \mathrm{C}$ for $5 \mathrm{~min}$. The reaction mixture was allowed to cool and the solution was centrifuged at $8000 \times g$ for $6 \mathrm{~min}$. Further, the absorbance of the supernatant was read at $540 \mathrm{~nm}$. One unit (U) of enzyme activity states the amount of enzyme releasing $1 \mu \mathrm{g}$ of reducing sugar as maltose per minute, under specific assay conditions. The bacterial biomass $(\mathrm{mg} / \mathrm{mL})$ was estimated by drying the pellets at $95^{\circ} \mathrm{C}$ until constant weight.

\subsection{Effect of Carbon Sources on Amylase Production}

Amylase production was estimated by growing the isolate into the basal medium containing various carbon sources such as glucose, starch, xylose, sucrose, lactose and mannose. Carbon sources at the concentration of $1 \%(w / v)$ were added separately to the production media. All the inoculated flasks were incubated at $37^{\circ} \mathrm{C}$ for $24 \mathrm{~h}$. The cell-free culture supernatant was used for the quantitative assay of extracellular amylase.

\subsection{Effect of Different Nitrogen Sources on Amylase Production}

To assess the effect of various nitrogen sources on the production of amylase, the production medium was inoculated individually with different organic and inorganic nitrogen sources such as peptone, yeast extract, beef extract, tryptone, potassium nitrate, ammonium sulphate and ammonium chloride at a concentration of $1 \%(w / v)$. Starch $(1 \% w / v)$ was used as the sole carbon source and the fermentation was carried out at $37^{\circ} \mathrm{C}$ for $24 \mathrm{~h}$.

\subsection{Effect of $p H$ on Amylase Production}

To study the effect of $\mathrm{pH}$ on enzyme production, the initial $\mathrm{pH}$ of the media was adjusted to a value between 5.0 and 10.0 before sterilization using $1 \mathrm{~N} \mathrm{HCl}$ and $1 \mathrm{~N} \mathrm{NaOH}$. Starch and yeast extract 
at a concentration of $1 \%(w / v)$ was used as carbon and nitrogen source respectively. Enzyme activities were determined in each flask as described earlier at $37^{\circ} \mathrm{C}$ after $24 \mathrm{~h}$ of incubation.

\subsection{Effect of Temperature on Amylase Production}

To evaluate the effect of temperature on amylase production from the isolate, the inoculated basal medium containing starch and yeast extract was incubated at different temperatures $\left(30-50^{\circ} \mathrm{C}\right)$ for $24 \mathrm{~h}$ with constant agitation at $130 \mathrm{rpm}$. $\mathrm{pH}$ of each inoculated flask was maintained at 7.0. The enzyme activities were determined as described earlier.

\subsection{Effect of Agitation Speed on Enzyme Production}

Aeration is one of the most critical variables for the successful implementation of aerobic fermentation. The tests were performed by varying the agitation speed ranging from 120 to $160 \mathrm{rpm}$ for optimizing the aerobic environment during shake flask cultivation. Amylase activities were determined at $35^{\circ} \mathrm{C}$ as described earlier.

\subsection{Effect of Incubation Period on Enzyme Production}

Optimization of incubation period is one of the most critical parameters in metabolic activity and growth of bacteria. To study the effect of incubation time on the production of enzyme, the inoculated medium was incubated for different time intervals ranging from 12 to $96 \mathrm{~h}$ and the amylase activity was estimated as described earlier.

\subsection{Temperature Stability of Crude Amylase}

Crude amylase was implemented for testing the stability of enzyme at various temperatures. The enzyme solution was incubated at varied temperatures ranging between 30 to $70^{\circ} \mathrm{C}$ for up to $4 \mathrm{~h}$. The relative enzyme activity was calculated at every $1 \mathrm{~h}$ interval as mentioned earlier.

\subsection{3. pH Stability of Crude Amylase}

The enzyme was incubated at varying $\mathrm{pH}$ ranging from 5 to 10 in different buffers $(0.1 \mathrm{M})$ such as Sodium phosphate ( $\mathrm{pH} 5.0$ to 7.0 ), Tris- $\mathrm{HCl}(\mathrm{pH} 8.0,9.0)$ and Carbonate-bicarbonate ( $\mathrm{pH} 10.0)$ in order to determine the $\mathrm{pH}$ stability of amylase. The crude enzyme was incubated into the respective buffer up to $4 \mathrm{~h}$ at optimum temperature and the relative enzyme activity was calculated at every $1 \mathrm{~h}$ interval as mentioned before.

\subsection{Optimization of Different Variables for Amylase Production by Response Surface Methodology}

Based upon the previous results obtained from the OFAT method, a statistical method, BBD was adopted to optimize the most important independent variables $(\mathrm{pH}$, temperature, agitation speed and incubation time) to maximize amylase production and biomass yield by keeping carbon and nitrogen sources constant. BBD is an optimization method for a small number of variables that estimates best fit parameters of the quadratic models. It detects not only the lack of fit of the model, but also constructs a sequential design for response surface methodology. According to the present experimental design, the total number of treatment combinations is $2^{k}+2 k+n$, where " $k$ " is the number of independent variables and " $n$ " is the number of repetition of experiments at the central point.

The experimental design consisted of 29 experiments of four variables (A, B, C and D) at three levels $(-1,0,+1)$ in order to optimize the medium components. The coded values -1 and +1 indicate low and high levels of the variables studied based on our previous experiments. All variables were set at a central coded value of zero.

Table 1 shows the experimental strategy of selected factors in terms of actual and coded form. The average amylase activity obtained was taken as dependent variable $(Y)$. On the other hand, 
biomass was also expressed as dependent variable $(Z)$ in terms of $\mathrm{mg} / \mathrm{mL}$. The effects of variables to the response were analyzed by using a second-order polynomial equation

$$
\begin{aligned}
& Y, Z=\beta_{0}+\Sigma \beta_{\mathrm{i}} X_{\mathrm{i}}+\Sigma \beta_{\mathrm{ii}} X_{\mathrm{i}}^{2}+\Sigma \beta_{\mathrm{ij}} X_{\mathrm{i}} X_{\mathrm{j}} \\
& \text { where, } Y \text { and } Z=\text { predicted response } \\
& \beta_{0}=\text { intercept term } \\
& \beta_{\mathrm{i}}=\text { linear effect } \\
& \beta_{\mathrm{ii}}=\text { squared effect } \\
& \beta_{\mathrm{ij}}=\text { interaction effect } \\
& X_{\mathrm{i}}, X_{\mathrm{j}}=\text { independent variables }
\end{aligned}
$$

The goodness of fit of the polynomial equation was expressed by coefficient of determination $R^{2}$ and its statistical significance level was checked by $F$ test. The desirability was kept at maximum.

\subsection{Validation of the Experimental Design}

The statistical analysis was validated for amylase production and biomass estimation in shake flask conditions using optimized parameters. The experiments were carried out in triplicate and the enzyme activity along with biomass yield was estimated according to the protocol described earlier.

\subsection{Statistical Analysis and Software Used}

All the experiments were performed in triplicate and values were expressed in terms of mean \pm SD. The independent variables of the experimental design were optimized and interpreted using Design Expert Version 10.0.0 (Stat-Ease Inc., Minneapolis, MN, USA) statistical software. The validation of statistical parameters was determined using ANOVA.

\section{Results}

\subsection{Isolation and Identification of Amylase-Producing Bacteria}

The hyperamylase-producing bacterium was isolated from the feces soil sample of poultry farm based on the clear halo zone around the colony appeared on the starch agar plate. The selected bacterial colony confirmed the production of amylase by further qualitative enzyme assay using the streak plate technique (Figure 1a).

The morphological and biochemical characteristics of the isolate based on the standard Bergey's Manual of Systemic Bacteriology confirmed the strain belonging to the genus Bacillus. Further, the microscopic observation of the isolate after staining showed purple rod-shaped bacterium (Figure 1b). An amplicon of $740 \mathrm{bp}$ size (figure not shown) was observed through PCR amplification and sequencing. The sequence was subjected to a multiple sequence alignment using the BLAST programme of NCBI. The sequence of isolate was deposited in GenBank, maintained by NCBI, USA (Accession No.: KC424491). The phylogenetic tree (Figure 2) was constructed using bioinformatics software MEGA 4 (The Biodesign Institute, Tempe, AZ, USA).
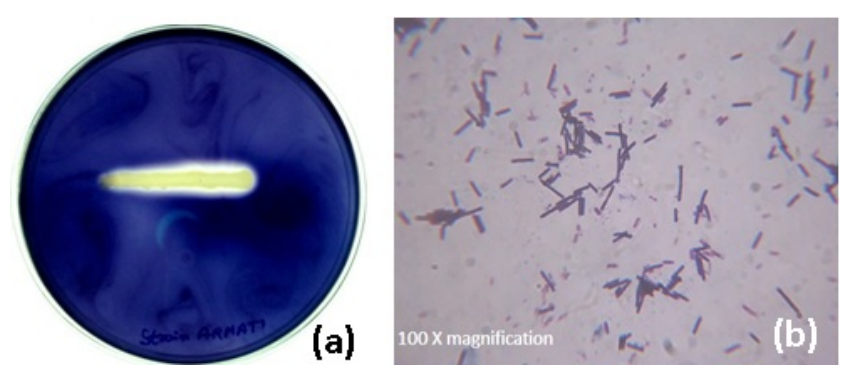

Figure 1. Streaking of Bacillus sp. on starch agar plate showed clear surrounding zone after flooding the plate with iodine solution (a); Microscopic observation of Bacillus sp. at $100 \times$ magnification showed rod-shaped purple cells (b). 


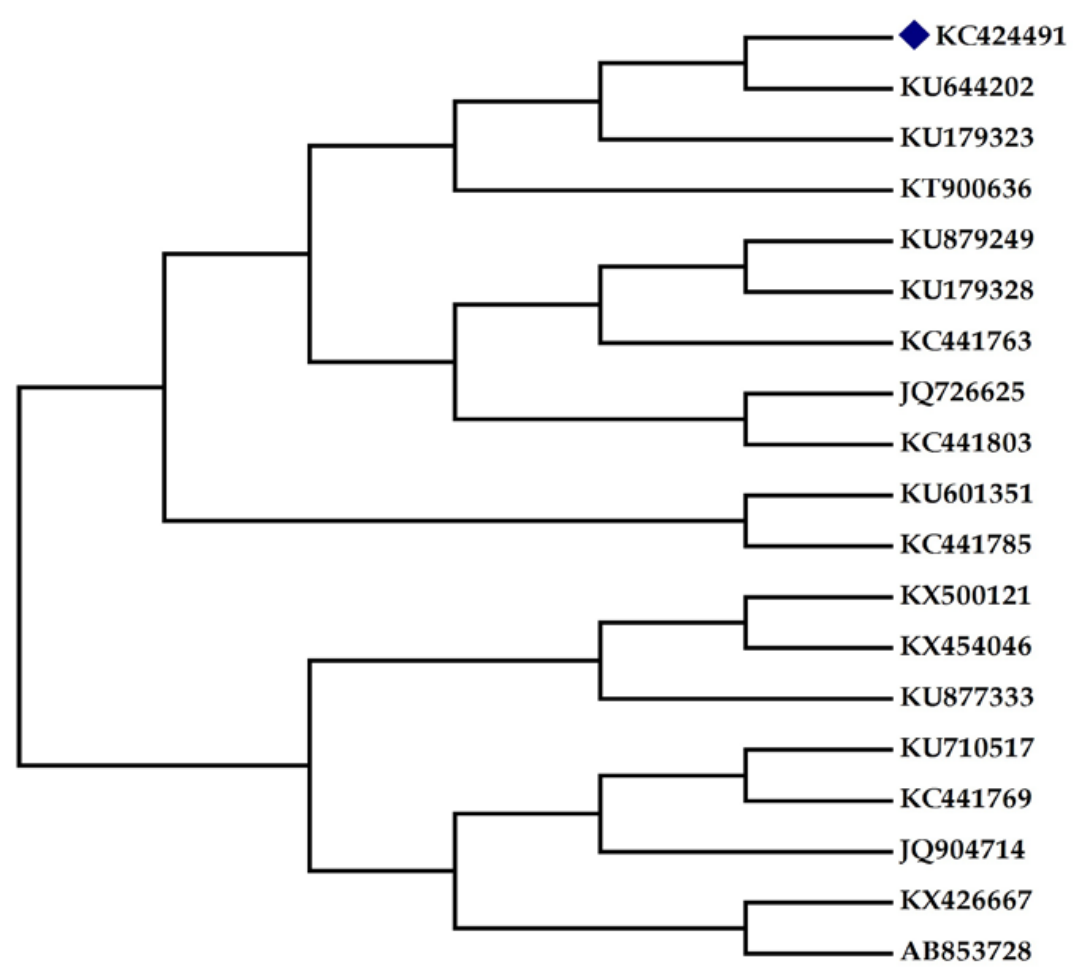

Figure 2. Phylogenetic tree based on the 16S rRNA sequences of isolate and its closest Bacillus sp. (Accession numbers). The Accession number with blue colour bullet indicates the Bacillus sp. of present investigation

\subsection{Effect of Carbon and Nitrogen Sources on Amylase Production}

The effect of various carbon sources on the production of extracellular amylase from Bacillus sp. revealed that among the carbon sources used, starch $(1 \% w / v)$ was found to be the best inducer of amylase production $(80.12 \pm 1.8 \mathrm{U} / \mathrm{mL})$ followed by glucose $(70.14 \pm 1.6 \mathrm{U} / \mathrm{mL})$. A significant reduction in the amylase activity of the isolate was observed when xylose, sucrose, lactose and mannose were inoculated into the basal medium as sole carbon source (figure not shown).

Amylase production was estimated in the presence of different organic and inorganic nitrogen sources using starch $(1 \% w / v)$ as a substrate. Supplementation of the medium with yeast extract $(1 \% w / v)$ showed maximum productivity $(80.45 \pm 2.2 \mathrm{U} / \mathrm{mL})$ of the enzyme (figure not shown). On the other hand, amylase activity was found to be extremely low $(40.67 \pm 1.6 \mathrm{U} / \mathrm{mL})$ in the production medium inoculated with ammonium chloride $(1 \% w / v)$.

\subsection{Effect of $\mathrm{pH}$ on Amylase Production}

$\mathrm{pH}$ of the production medium ranging from 5 to 10 showed profound effect on the amylase activity (figure not shown). Neutral medium ( $\mathrm{pH} 7.0$ ) was found to be the best parameter in order to show maximum productivity $(85.24 \pm 2.3 \mathrm{U} / \mathrm{mL})$ of the enzyme. There was significant reduction in the amylase activity at alkaline $\mathrm{pH}$.

\subsection{Effect of Temperature on Enzyme Production}

Temperature is one of the effective physical factors responsible for the change in the enzyme production. Bacillus sp. showed maximum enzyme titer $(90.42 \pm 2.1 \mathrm{U} / \mathrm{mL})$ at $35^{\circ} \mathrm{C}$. Further increase in the temperature to 40 and $50^{\circ} \mathrm{C}$ inhibited the amylase production indicating the organism mesophilic in nature (figure not shown). 


\subsection{Effect of Agitation and Incubation Period on Enzyme Production}

Aeration and incubation time are the most important factors for the maximum production of enzyme in a cost-effective manner. The influence of varying agitation for amylase activity was evaluated and the isolate showed maximum enzyme activity $(93.76 \pm 1.8 \mathrm{U} / \mathrm{mL}$ ) at $130 \mathrm{rpm}$ (figure not shown). On the other hand, the highest enzyme production $(98.56 \pm 2.2 \mathrm{U} / \mathrm{mL})$ was observed after $24 \mathrm{~h}$ of incubation (figure not shown).

\subsection{Effect of Temperature and $\mathrm{pH}$ on the Stability of Crude Amylase}

Stability is one of the most important factors in studying characteristics of an enzyme. Crude amylase obtained from Bacillus sp. showed stability until $60^{\circ} \mathrm{C}$ for $4 \mathrm{~h}$ of incubation and retained upto $51 \%$ of the activity. The enzyme stability was reduced significantly above $60^{\circ} \mathrm{C}$ (figure not shown).

The crude amylase obtained from Bacillus sp. was stable at a wide range of $\mathrm{pH}$ from 5.0 to 9.0. The isolate was found stable upto $\mathrm{pH} 9.0$ for $4 \mathrm{~h}$ of incubation. About $66.13 \%$ of activity was retained by Bacillus sp. upto $\mathrm{pH} 9.0$ (figure not shown).

\subsection{Optimization of Independent Variables using Response Surface Methodology}

The independent variables such as $\mathrm{pH}$, temperature, agitation rate and incubation period were identified as significant parameters based on the preliminary investigation (Table 2). These variables were further optimized by RSM using BBD. BBD, consisting of 29 experiments with three levels of four variables in coded, experimental and predicted values of amylase activity and biomass yield is shown in Table 1.

Table 1. Box-Behnken design along with experimental and predicted values of dependent variable for amylase activity and biomass production.

\begin{tabular}{|c|c|c|c|c|c|c|c|c|}
\hline \multirow{2}{*}{ Run Order } & \multirow{2}{*}{ A } & \multirow{2}{*}{ B } & \multirow{2}{*}{$\mathrm{C}$} & \multirow{2}{*}{ D } & \multicolumn{2}{|c|}{ Amylase Activity (U/mL) } & \multicolumn{2}{|c|}{ Biomass (mg/mL) } \\
\hline & & & & & Experimental & Predicted & Experimental & Predicted \\
\hline 1 & 0 & 0 & 0 & 0 & 145.32 & 136.71 & 4.5 & 4.28 \\
\hline 2 & 0 & 0 & +1 & -1 & 90.42 & 87.87 & 1.1 & 0.97 \\
\hline 3 & 0 & -1 & 0 & +1 & 102.14 & 98.25 & 1.6 & 1.43 \\
\hline 4 & +1 & -1 & 0 & 0 & 85.64 & 84.47 & 0.98 & 0.86 \\
\hline 5 & 0 & 0 & -1 & +1 & 80.14 & 86.68 & 0.76 & 0.92 \\
\hline 6 & -1 & +1 & 0 & 0 & 70.12 & 75.28 & 0.65 & 0.8 \\
\hline 7 & 0 & +1 & 0 & -1 & 110.14 & 106.13 & 1.4 & 1.43 \\
\hline 8 & 0 & +1 & 0 & +1 & 95.12 & 87.11 & 1 & 0.85 \\
\hline 9 & 0 & 0 & +1 & +1 & 90.02 & 91.22 & 1.2 & 1.14 \\
\hline 10 & 0 & +1 & +1 & 0 & 100.44 & 101.31 & 1.3 & 1.2 \\
\hline 11 & 0 & +1 & -1 & 0 & 98.12 & 99.43 & 0.9 & 0.88 \\
\hline 12 & 0 & -1 & +1 & 0 & 90.14 & 92.74 & 0.8 & 0.93 \\
\hline 13 & +1 & 0 & -1 & 0 & 92.67 & 83.90 & 0.91 & 0.66 \\
\hline 14 & 0 & 0 & -1 & -1 & 80.76 & 83.55 & 0.85 & 0.93 \\
\hline 15 & 0 & -1 & -1 & 0 & 82.73 & 85.77 & 0.78 & 0.99 \\
\hline 16 & -1 & 0 & +1 & 0 & 67.14 & 68.02 & 0.53 & 0.64 \\
\hline 17 & 0 & 0 & 0 & 0 & 130.24 & 136.71 & 4.3 & 4.28 \\
\hline 18 & 0 & 0 & 0 & 0 & 135.54 & 136.71 & 4.2 & 4.28 \\
\hline 19 & +1 & 0 & 0 & +1 & 78.96 & 83.22 & 0.64 & 0.81 \\
\hline 20 & -1 & -1 & 0 & 0 & 62.14 & 61.45 & 0.65 & 0.59 \\
\hline 21 & 0 & 0 & 0 & 0 & 140.12 & 136.71 & 4.2 & 4.28 \\
\hline 22 & -1 & 0 & -1 & 0 & 66.14 & 61.24 & 0.71 & 0.52 \\
\hline 23 & -1 & 0 & 0 & -1 & 60.02 & 59.67 & 0.65 & 0.59 \\
\hline 24 & -1 & 0 & 0 & +1 & 62.18 & 62.09 & 0.72 & 0.77 \\
\hline 25 & 0 & -1 & 0 & -1 & 72.65 & 72.76 & 0.68 & 0.69 \\
\hline 26 & +1 & 0 & 0 & -1 & 75.16 & 79.16 & 0.76 & 0.83 \\
\hline 27 & 0 & 0 & 0 & 0 & 132.34 & 136.71 & 4.18 & 4.28 \\
\hline 28 & +1 & 0 & +1 & 0 & 88.98 & 85.98 & 0.74 & 0.79 \\
\hline 29 & +1 & +1 & 0 & 0 & 88.20 & 92.88 & 0.72 & 0.81 \\
\hline
\end{tabular}


Table 2. Experimental range, level and code of independent variables for Box-Behnken design.

\begin{tabular}{ccccc}
\hline \multirow{2}{*}{ Variables } & \multirow{2}{*}{ Code } & \multicolumn{3}{c}{ Range and Levels } \\
\cline { 3 - 5 } & & $\mathbf{- 1}$ & $\mathbf{0}$ & $\mathbf{+ 1}$ \\
\hline $\mathrm{pH}$ & $\mathrm{A}$ & 4 & 6 & 8 \\
Temperature $\left({ }^{\circ} \mathrm{C}\right)$ & $\mathrm{B}$ & 25 & 35 & 45 \\
Agitation speed $(\mathrm{rpm})$ & $\mathrm{C}$ & 120 & 130 & 140 \\
Incubation period $(\mathrm{h})$ & $\mathrm{D}$ & 12 & 24 & 48 \\
\hline
\end{tabular}

All the experiments based on the 29 experimental runs were performed in a $250 \mathrm{~mL}$ Erlenmeyer flask containing $50 \mathrm{~mL}$ of basal media. The production of amylase $(Y)$ was predicted by the following model equation:

$$
\begin{gathered}
Y(\mathrm{U} / \mathrm{mL})=136.71+10.16 A+5.56 B+2.21 C+1.62 D-1.36 A B-1.17 A C+0.41 A D- \\
1.27 B C-11.13 B D+0.055 C D-39.11 A^{2}-19.08 B^{2}-22.82 C^{2}-26.57 D^{2}
\end{gathered}
$$

The biomass production $(Z)$ was estimated by the following model equation:

$$
\begin{gathered}
Z(\mathrm{mg} / \mathrm{mL})=4.28+0.07 A+0.04 B+0.063 C+0.04 D-0.065 A B+2.500 \mathrm{E}-003 A C- \\
0.047 A D+0.095 B C-0.033 B D+0.047 C D-1.93 A^{2}-1.58 B^{2}-1.69 C^{2}-1.59 D^{2}
\end{gathered}
$$

The quadratic model represents amylase activity $(Y)$ and biomass production $(Z)$ as a function of $\mathrm{pH}(A)$, temperature $(B)$, agitation speed $(C)$ and incubation period $(D) . F$ test determines the statistical significance of the second-order quadratic model equation.

Table 3 indicates ANOVA for response surface quadratic model of enzyme. The significance level of each of the coefficients is determined by observing the $p$ value ( $p$ value $<0.05=$ significant). The model is considered significant based on the $F$ value (31.03). There is probability of only $0.01 \%$ that a large "Model F value" could occur due to noise. In the present study, model terms such as A, $\mathrm{BD}, \mathrm{A}^{2}, \mathrm{~B}^{2}, \mathrm{C}^{2}$ and $\mathrm{D}^{2}$ are found to be significant (Table 3). On the other hand, the "Lack of Fit $F$-value" of 0.99 indicates it is non-significant which is good for the model to fit. The multiple correlation coefficient $\left(R^{2}\right)$ was found to be close to 1 which indicates an accurate model with perfect response. Similarly, a low coefficient of variation $(\mathrm{CV})$ of $6.58 \%$ indicates the reliable and précised experiments.

\begin{tabular}{|c|c|c|c|c|c|c|}
\hline \multirow{2}{*}{$\begin{array}{l}\text { Source } \\
\text { Model }\end{array}$} & \multirow{2}{*}{$\begin{array}{c}\text { Sum of Squares } \\
16,001.80\end{array}$} & \multirow{2}{*}{$\frac{D f}{14}$} & \multirow{2}{*}{$\begin{array}{c}\text { Mean Square } \\
1142.99\end{array}$} & \multirow{2}{*}{$\begin{array}{c}\text { F Value } \\
31.03\end{array}$} & \multicolumn{2}{|c|}{$p$-Value Prob $>F$} \\
\hline & & & & & $<0.0001$ & Significant \\
\hline A & 1237.69 & 1 & 1237.69 & 33.60 & $<0.0001$ & \\
\hline B & 370.74 & 1 & 370.74 & 10.07 & 0.0068 & \\
\hline $\mathrm{C}$ & 58.87 & 1 & 58.87 & 1.60 & 0.2268 & \\
\hline $\mathrm{D}$ & 31.40 & 1 & 31.40 & 0.85 & 0.3715 & \\
\hline$A B$ & 7.34 & 1 & 7.34 & 0.20 & 0.6620 & \\
\hline $\mathrm{AC}$ & 5.50 & 1 & 5.50 & 0.15 & 0.7050 & \\
\hline $\mathrm{AD}$ & 0.67 & 1 & 0.67 & 0.018 & 0.8944 & \\
\hline $\mathrm{BC}$ & 6.48 & 1 & 6.48 & 0.18 & 0.6813 & \\
\hline $\mathrm{BD}$ & 495.29 & 1 & 495.29 & 13.45 & 0.0025 & \\
\hline $\mathrm{CD}$ & 0.012 & 1 & 0.012 & $3.285 \mathrm{E}-004$ & 0.9858 & \\
\hline $\mathrm{A}^{2}$ & 9922.19 & 1 & 9922.19 & 269.39 & $<0.0001$ & \\
\hline $\mathrm{B}^{2}$ & 2361.94 & 1 & 2361.94 & 64.13 & $<0.0001$ & \\
\hline$C^{2}$ & 3377.04 & 1 & 3377.04 & 91.69 & $<0.0001$ & \\
\hline $\mathrm{D}^{2}$ & 4577.85 & 1 & 4577.85 & 124.29 & $<0.0001$ & \\
\hline Residual & 515.65 & 14 & 36.83 & & & \\
\hline Lack of Fit & 367.56 & 10 & 36.76 & 0.99 & 0.5517 & Not significant \\
\hline Pure Error & 148.09 & 4 & 37.02 & & & \\
\hline Cor Total & $16,517.45$ & 28 & & & & \\
\hline
\end{tabular}

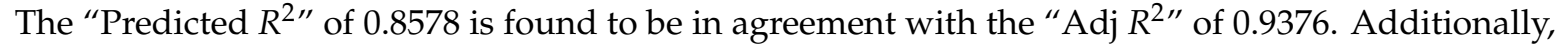
"Adeq Precision" ratio of 17.651 also indicates an adequate signal.

Table 3. Analysis of variance (ANOVA) for amylase activity as a function of independent variables.

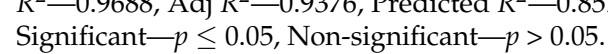


Table 4 shows ANOVA for quadratic model of bacterial biomass. Model terms having $p$ value $<0.05$ were considered significant and the model is found to be significant due to $F$ value of 108.19. In this study, model terms such as $\mathrm{A}^{2}, \mathrm{~B}^{2}, \mathrm{C}^{2}, \mathrm{D}^{2}$ and $\mathrm{BD}$ are found to be significant. The "Lack of Fit" is non-significant which is good for the model to fit. A better correlation between experimental and predicted values was obtained due to $R^{2}$ value (0.9908) closer to 1 . A low coefficient of variation $(\mathrm{CV})$ of $12.31 \%$ denotes that the experiments performed are highly reliable and precise. Additionally, the "Predicted $R^{2 "}$ of 0.9533 is found to be in reasonable agreement with the "Adj $R^{2 "}$ of 0.9817 .

Table 4. Analysis of variance (ANOVA) for biomass yield as a function of independent variables.

\begin{tabular}{|c|c|c|c|c|c|c|}
\hline \multirow{2}{*}{$\begin{array}{l}\text { Source } \\
\text { Model }\end{array}$} & \multirow{2}{*}{$\frac{\text { Sum of Squares }}{49.11}$} & \multirow{2}{*}{$\begin{array}{c}D f \\
14\end{array}$} & \multirow{2}{*}{$\frac{\text { Mean Square }}{3.51}$} & \multirow{2}{*}{$\begin{array}{c}\boldsymbol{F} \text { Value } \\
108.19\end{array}$} & \multicolumn{2}{|c|}{$p$-Value Prob $>F$} \\
\hline & & & & & $<0.0001$ & Significant \\
\hline A & 0.059 & 1 & 0.059 & 1.81 & 0.1995 & \\
\hline B & 0.019 & 1 & 0.019 & 0.59 & 0.4544 & \\
\hline $\mathrm{C}$ & 0.048 & 1 & 0.048 & 1.48 & 0.2432 & \\
\hline $\mathrm{D}$ & 0.019 & 1 & 0.019 & 0.59 & 0.4544 & \\
\hline $\mathrm{AB}$ & 0.017 & 1 & 0.017 & 0.52 & 0.4822 & \\
\hline $\mathrm{AC}$ & 2.500E-005 & 1 & 2.500E-005 & 7.710E-004 & 0.9782 & \\
\hline $\mathrm{AD}$ & 9.025E-003 & 1 & 9.025E-003 & 0.28 & 0.6061 & \\
\hline $\mathrm{BC}$ & 0.036 & 1 & 0.036 & 1.11 & 0.3092 & \\
\hline $\mathrm{BD}$ & 0.44 & 1 & 0.44 & 13.43 & 0.0025 & \\
\hline CD & 9.025E-003 & 1 & 9.025E-003 & 0.28 & 0.6061 & \\
\hline $\mathrm{A}^{2}$ & 24.21 & 1 & 24.21 & 746.52 & $<0.0001$ & \\
\hline $\mathrm{B}^{2}$ & 16.23 & 1 & 16.23 & 500.52 & $<0.0001$ & \\
\hline$C^{2}$ & 18.56 & 1 & 18.56 & 572.55 & $<0.0001$ & \\
\hline $\mathrm{D}^{2}$ & 16.49 & 1 & 16.49 & 508.46 & $<0.0001$ & \\
\hline Residual & 0.45 & 14 & 0.032 & & & \\
\hline Lack of Fit & 0.38 & 10 & 0.038 & 2.14 & 0.2414 & Not significant \\
\hline Pure Error & 0.072 & 4 & 0.018 & & & \\
\hline Cor Total & 49.56 & 28 & & & & \\
\hline
\end{tabular}

Parity plot indicates the model as accurate and very satisfactory for amylase activity which shows the localization of predicted and experimental data close to diagonal lines (Figure 3).

The 3D plot (Figure 4a-f) provides a visual interpretation of the average interaction between two independent variables. Response surface curves were plotted to find the optimum level of each variable. The response surface plots were constructed by plotting the amylase activity on the $z$-axis against any two independent factors. The amylase production varied significantly upon changing the levels of independent variables. The maximum enzyme production was observed with respect to the central values of these variables. Figure 4 a represents response surface plot between two variables- $-\mathrm{pH}$ $\left(\mathrm{A} / \mathrm{X}_{1}\right)$ and temperature $\left(\mathrm{B} / \mathrm{X}_{2}\right)$. Both the factors showed significant effect on the amylase production. Maximum enzyme production was obtained when both the variables were at their middle to high level. There was gradual reduction in the amylase activity as the $\mathrm{pH}$ of the medium and incubation temperatures were increased further. 


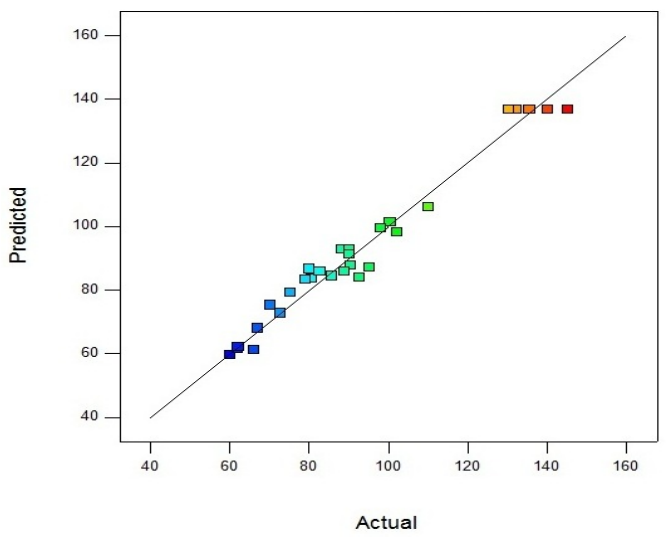

Figure 3. Distribution of experimental/actual and predicted values of amylase activity by Parity plot.
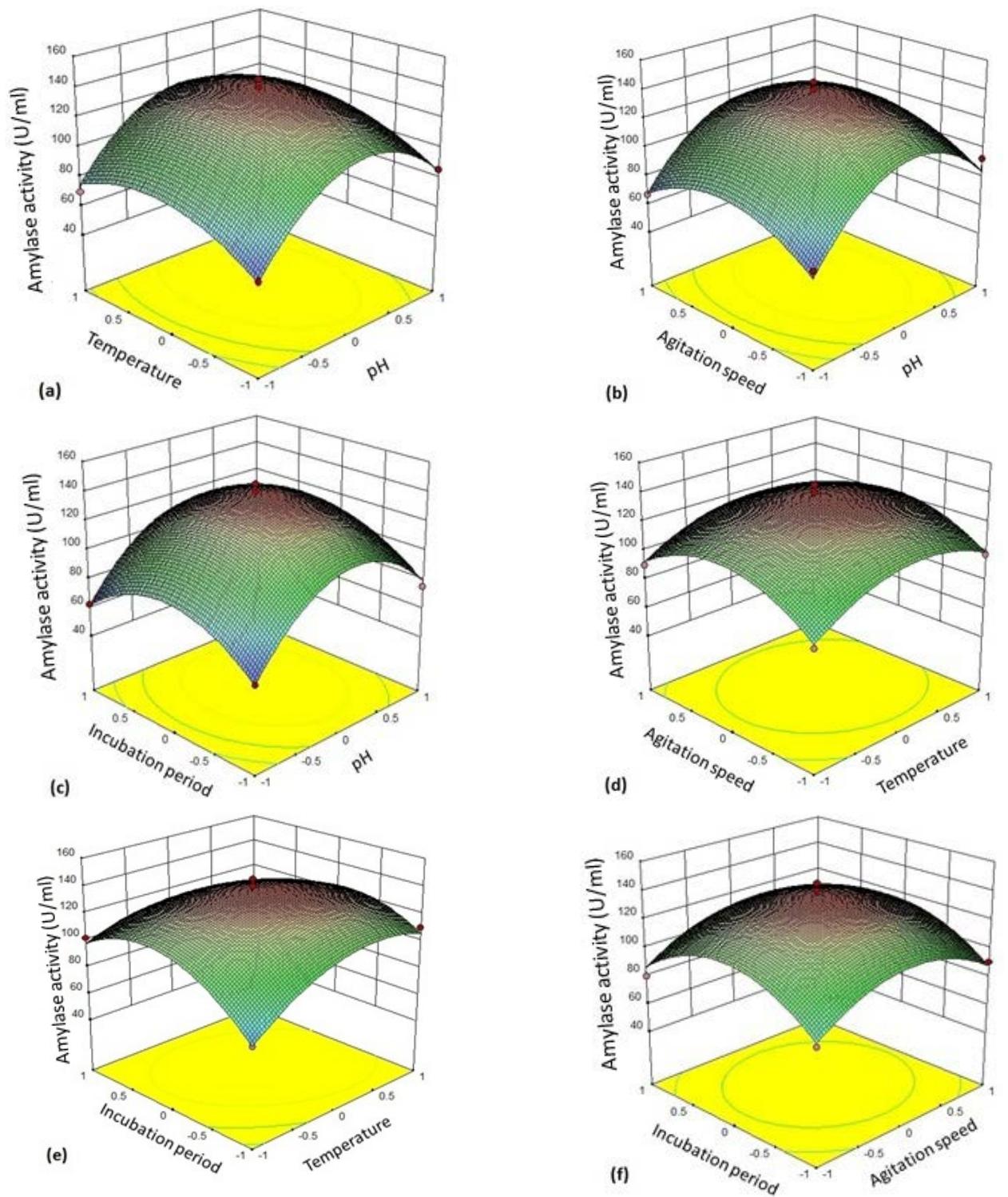

Figure 4. Response surface plot and interaction effect between (a) $\mathrm{pH}$ and temperature; (b) $\mathrm{pH}$ and agitation speed; (c) $\mathrm{pH}$ and incubation period; (d) temperature and agitation speed; (e) temperature and incubation period; and (f) agitation speed and incubation period. 
Figure $4 \mathrm{~b}$ depicts three-dimensional surface plot interaction between $\mathrm{pH}\left(\mathrm{A} / \mathrm{X}_{1}\right)$ and agitation rate $\left(\mathrm{C} / \mathrm{X}_{3}\right)$ for the production of amylase. It is clear from the interaction between these two variables that the amylase production was maximum at middle to slightly higher level of $\mathrm{pH}(6-7)$ and agitation speed (130-135 rpm). Both the factors at their lower and higher levels did not result in the enhancement of the amylase production.

Figure $4 \mathrm{c}$ establishes the significant interaction effect between $\mathrm{pH}\left(\mathrm{A} / \mathrm{X}_{1}\right)$ and incubation time $\left(\mathrm{D} / \mathrm{X}_{4}\right)$. The enzyme yield was maximum when the $\mathrm{pH}$ of the medium was at the middle to slightly higher level ( $\mathrm{pH} 6-7)$ and the fermentation period of $24-36 \mathrm{~h}$. Lower $(<24 \mathrm{~h})$ and higher $(>24 \mathrm{~h})$ incubation period resulted in reduction in amylase yield but $24 \mathrm{~h}$ incubation was found to be optimal.

Figure $4 \mathrm{~d}$ shows the response surface plot as a function of temperature $\left(\mathrm{B} / \mathrm{X}_{2}\right)$ and agitation rate $\left(\mathrm{C} / \mathrm{X}_{3}\right)$. An increase in amylase activity was observed in the production medium kept at $35^{\circ} \mathrm{C}$ at an agitation rate of 130-135 rpm.

Figure $4 \mathrm{e}$ illustrates the surface plot between temperature $\left(\mathrm{B} / \mathrm{X}_{2}\right)$ and incubation time $\left(\mathrm{D} / \mathrm{X}_{4}\right)$. The shape of response surface plot showed moderate interaction between these two independent variables. The enzyme yield was increased at lower to middle values of incubation time (18-24 h). On the other hand, there was significant enhancement in amylase production at the temperature range $35-40{ }^{\circ} \mathrm{C}$.

Figure $4 \mathrm{f}$ shows interaction between the variable agitation speed $\left(\mathrm{C} / \mathrm{X}_{3}\right)$ and incubation period $\left(\mathrm{D} / \mathrm{X}_{4}\right)$. Both the factors in their respective central value showed maximum yield of amylase.

Figure 5 shows 2D contour plot of biomass yield between the variables. The biomass of the bacteria was influenced by the variables optimized using BBD. Figure 5a shows the contour plot between $\mathrm{pH}$ and temperature for biomass concentration of bacteria. According to the plot, the biomass of the strain was enhanced effectively at the central values of the factors. $\mathrm{pH}$ and incubation temperature at respective lower and higher ranges resulted reduction in biomass of Bacillus sp. Similarly, the biomass of the bacteria was influenced effectively at the middle ranges of mutual interaction between $\mathrm{pH}$ and agitation speed (Figure $5 \mathrm{~b}$ ), $\mathrm{pH}$ and incubation period (Figure $5 \mathrm{c}$ ), temperature and agitation speed (Figure $5 \mathrm{~d}$ ) and agitation speed and incubation period (Figure 5f). On the other hand, Figure 5e illustrates that the biomass yield of the isolate was enhanced between the lower to middle range of temperature $\left(30-35^{\circ} \mathrm{C}\right)$, and middle to slightly higher level of incubation period (24-36 h). The optimized parameters enhancing the biomass yield is more or less equivalent to the optimized variables' ranges enhancing amylase production by the isolate.
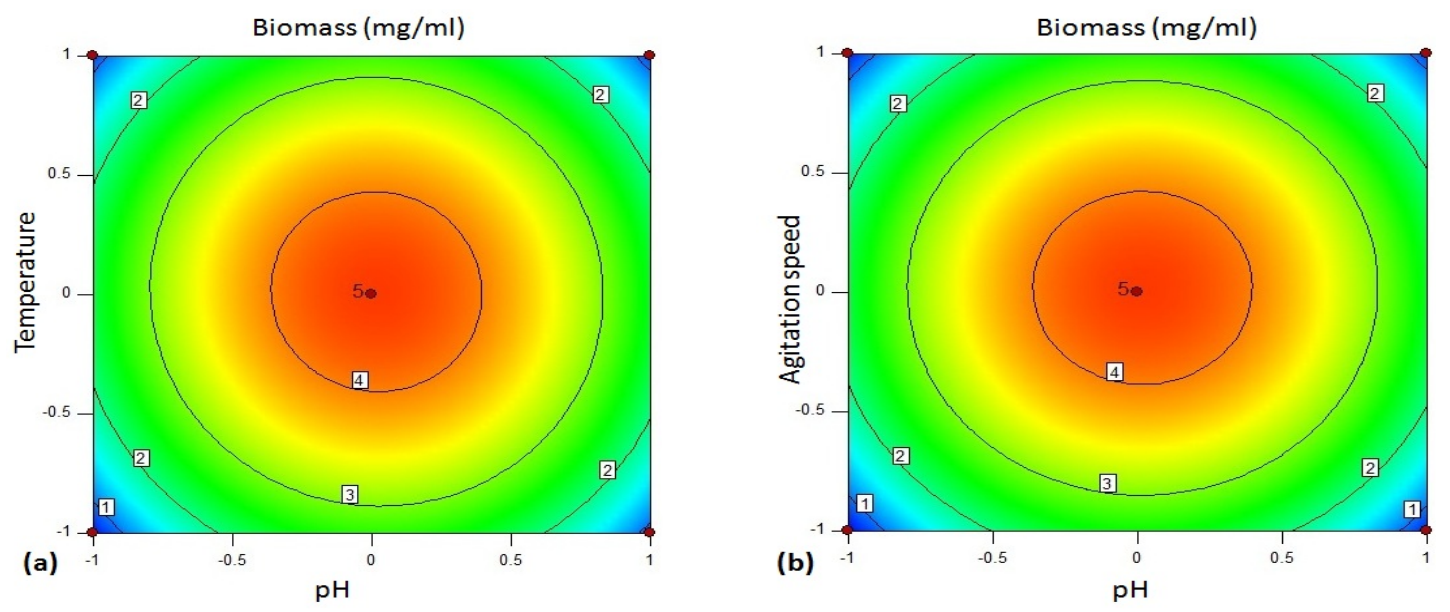

Figure 5. Cont. 

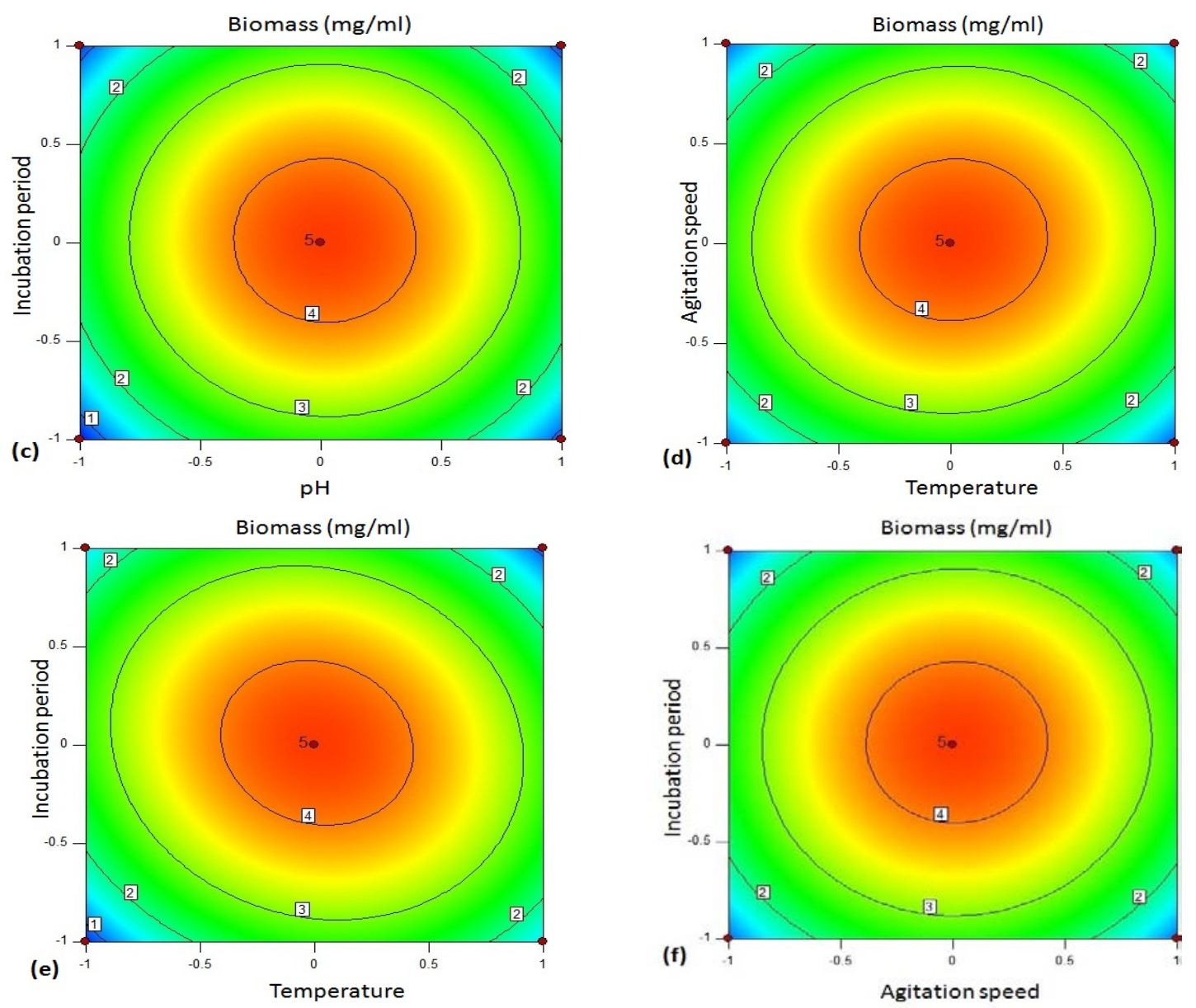

Figure 5. 2D Contour plot showing interaction between (a) $\mathrm{pH}$ and temperature (b) $\mathrm{pH}$ and agitation speed (c) $\mathrm{pH}$ and incubation period (d) temperature and agitation speed (e) temperature and incubation period (f) agitation speed and incubation period for biomass estimation in Bacillus sp.

Validation of model was done by conducting experiments in triplicate using predicted optimized parameters by BBD. Highest amylase activity was observed with experimental run order number 1 using $\mathrm{pH}-6$, temperature $-35^{\circ} \mathrm{C}$, agitation rate $-130 \mathrm{rpm}$ and $24 \mathrm{~h}$ of incubation time. The maximum amylase production by Bacillus sp. was $145.32 \mathrm{U} / \mathrm{mL}$ which was found very close to the predicted value, i.e., $136.71 \mathrm{U} / \mathrm{mL}$. The maximum biomass yield obtained was $4.5 \mathrm{mg} / \mathrm{mL}$ at similar ranges and levels of variables with experimental run order number 1.

Figure 6a shows perturbation graphs by changing one factor and keeping other factors constant. The graph compares the effect of variables optimized using RSM. Amylase activity was found to be affected by C (agitation speed) and B (temperature) followed by D (incubation period) and A ( $\mathrm{pH}$ ). On the other hand, biomass yield (Figure $6 \mathrm{~b}$ ) of Bacillus sp. was affected by incubation time (D) and incubation temperature (B) followed by agitation speed (C) and $\mathrm{pH}(\mathrm{A})$.

The adequate accuracy of fitted model with the experimental values is an important criterion in RSM. One of the most important criteria to judge the accuracy of the model is to check the residual from the least squares. Figure 7 shows the interaction between internally studentized residuals and normal percentage probability for biomass yield. The graph was constructed to check the normality assumption. The normality assumption vs internally studentized residuals were found to be satisfactory due to the plot obtained in a straight line. 

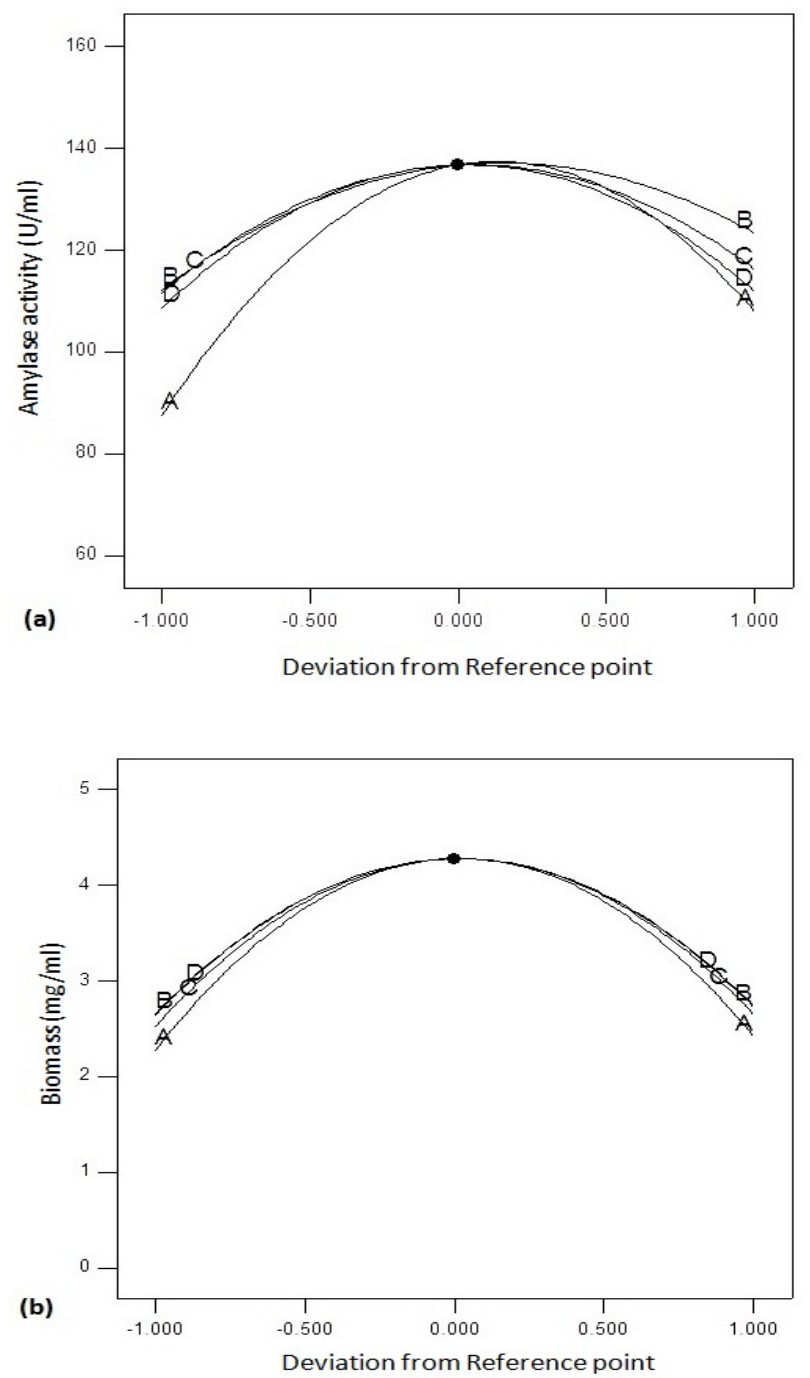

Figure 6. Perturbation graphs for variables A ( $\mathrm{pH}), \mathrm{B}$ (temperature), C (agitation speed) and D (incubation period) in amylase production (a) and biomass yield (b).

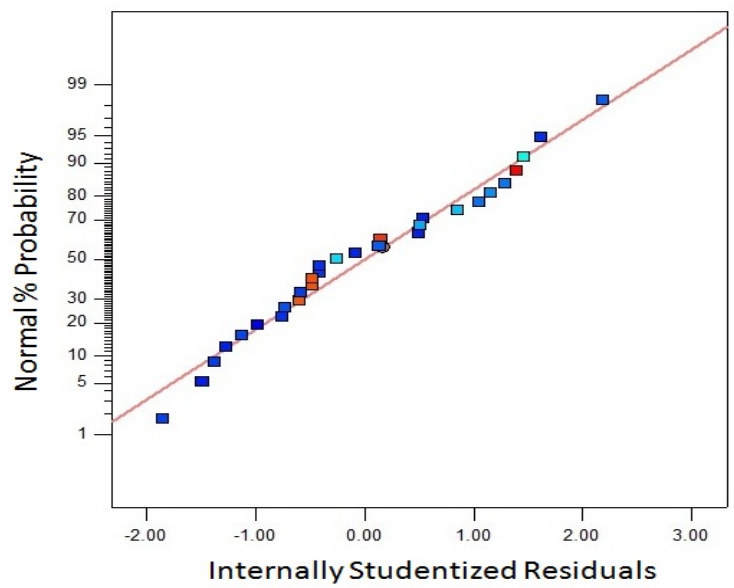

Figure 7. Interaction between internally studentized residuals and normal percentage probability for biomass yield. 


\section{Discussion}

The medium constituents and culture conditions were found to have profound influence on extracellular amylase production. Carbon is not only an important medium component, but also one of the essential elements for the growth and metabolism of bacteria resulting in stimulation of enzyme production. In the present context, the optimal level of amylase from Bacillus sp. was recorded when starch was used as a sole carbon source. Our results totally agree with the findings of Samanta et al. [12] and Karatas et al. [13] who demonstrated maximum amylase production in the presence of starch. On the other hand, Deb et al. [14] and Abd-Elhalem et al. [5] had recorded maximum amylase production from Bacillus sp. in the presence of corn flour and different agro-industrial wastes respectively. In contrast to our findings, Kumarai et al. [14] and Birgit Kamm and Michael Kamm [15] stated that rice starches and maize starches were suitable substrates for the amylase production from Bacillus sp. In a similar manner, Choubane et al. [16] utilized pasta cooking water for the production of amylase from Bacillus sp.

According to the present investigation, starch plays a major role as inducer in the culture medium for stimulating the amylase yield because starch is a complex carbohydrate and it is metabolized by the bacteria in a slower manner and thus, accumulates maximum amylase in the fermentation broth. The significant reduction in amylase production at lower or higher concentration of starch might be due to the unavailability of dissolved oxygen to the bacteria because of the presence of high concentration or viscosity of carbon source in the medium. Among diversiform organic and inorganic nitrogen sources tested, yeast extract was found to be the potent nitrogen source for the isolate in order to achieve maximum production of amylase. The present investigation was in complete agreement with the findings of Ravindar and Elangovan [3] and Dash et al. [13]. Similar to our findings, Salman et al. [17] also demonstrated that yeast extract was a potent nitrogen source for amylase production from Bacillus sp. Yeast extract had been reported to play an important role in enzyme production due to the presence of essential elements, coenzymes, nitrogenous constituents and growth factors [15]. However, our reports were against the observations of Bozic et al. [18] who demonstrated casein to be the best nitrogen source for amylase production from Bacillus sp.

In the present context, Bacillus sp. showed enhanced amylase activity at neutral $\mathrm{pH}$. The study reported the findings as more or less similar to the investigations of Nusrat and Rahman [19] and Asgher et al. [20], who demonstrated maximum amylase production from Bacillus sp. at slightly neutral $\mathrm{pH}$. A change in the $\mathrm{pH}$ of the medium alters the ionization of nutrient molecules and reduces their availability to the microorganisms that results in reduction of their metabolic activity [21]. When the $\mathrm{pH}$ of the medium is altered, it results in the reduction of amylase activity due to the denaturation of proteins.

Temperature had profound impact on amylase production. Bacillus sp. showed maximum amylase activity at $35{ }^{\circ} \mathrm{C}$, but amylase reported in previous studies had optimum temperature of $37-70{ }^{\circ} \mathrm{C}[22,23]$. The variations among our reports and the previous studies might be due to the different source of the bacterial isolation as well as types of strains. Low enzyme production at high temperature shows sensitiveness of the isolate to the temperature. Amylase must collide with and bind to the substrate at the active site in order to achieve products from the starch. Changing the temperature of a system will increase or decrease the number of collisions of enzyme and substrate per unit time. Thus, the rate of the reaction will change. Change in the temperature affects the growth of the bacteria, causing alteration in the amylase production. For the mesophilic bacteria, as the temperature of the system increases, it causes thermal denaturation of the protein and enzymes.

According to the reports of the present context, maximum amylase activity by Bacillus sp. was observed at $130 \mathrm{rpm}$. Agitation rate in the range of 100 to $250 \mathrm{rpm}$ had also been reported for the enhanced production of amylases [24].

The current study demonstrated that the maximum production of amylase by Bacillus sp. was obtained at $24 \mathrm{~h}$ of incubation period. A significant reduction in enzyme activity afterwards was because of the successive depletion of essential nutrients in the culture medium, resulting in an 
unfavorable environment for the bacteria. The current investigation strongly agreed with the findings of Dash et al. [13] who demonstrated significant amylase yield from Bacillus sp. at the end of $24 \mathrm{~h}$. Conversely, Abd-Elhalem et al. [5] demonstrated the maximum yield of amylase from Bacillus sp. during $36 \mathrm{~h}$ of incubation. Findings of the corresponding experiments revealed that the time course of enzyme production varies with the source of isolation, type of strain, genetic makeup of strain and cultivation conditions.

In the present investigation, crude amylase obtained from Bacillus sp. was more stable up to $60{ }^{\circ} \mathrm{C}$ for $4 \mathrm{~h}$ of incubation and retained upto 51\% of the activity. Our study supported more or less the findings of Guleria and Chatanta [25] and Sharma et al. [26] who obtained amylase stability at $50{ }^{\circ} \mathrm{C}$. However, our findings show superiority to Samanta et al. [12] who demonstrated the stability of crude amylase at $40{ }^{\circ} \mathrm{C}$, while the enzyme activity was lost at higher temperature. In the same manner, Deb et al. [27] reported the stability of Bacillus sp.-associated amylase up to $50{ }^{\circ} \mathrm{C}$ only and a drastic reduction in the relative activity of enzyme was observed at higher temperature $\left(>50^{\circ} \mathrm{C}\right)$. Significant enzyme stability at higher temperatures, as obtained in the present context, would be important for several industrial processes. The most important property of the isolate of the present study was alkali-tolerant nature of crude amylase obtained. The finding of this study was found more or less similar to the observations of Sharma et al. [26] and Asgher et al. [20] who obtained alkali-tolerant amylase. However, our study was against the reports of Samanta et al. [12], who found the stability of crude amylase within the range of $\mathrm{pH}$ 6-8 only. A large number of bacteria secrete amylase at neutral $\mathrm{pH}$ but enzyme shows stability at higher $\mathrm{pH}$. The alkali-stable enzymes constitute a decreased and increased number of acidic residues and arginines respectively [28]. Bacillus sp. of the present study could be a potent and biotechnologically important organism for industrial applications due to the alkali-tolerant property of amylase.

Medium composition and the physical parameters affect the growth and enzyme production rate of the bacteria. Hence, there is an urgent need to improve enzyme productivity by optimizing physical factors and medium components required for the growth and utilization of bacteria at the industrial scale. Zhao et al. [29] and Prajapati et al. [30] reported similar studies on the enhancement in amylase production by Bacillus sp. using statistical tools. In our study, amylase yield was found to be influenced by optimizing $\mathrm{pH}$, temperature, agitation and incubation period using BBD. A good correlation between the experimental and predicted values verified the model and established the existence of the optimal points. The minor differences between experimental and predicted results were due to the determination coefficients.

It is clear from the 3D response plot that the model predicts the optimum region for amylase production at more or less central values of the variables. The elliptical nature of the $2 \mathrm{D}$ contour indicates significant interaction between the independent factors, whereas the circular contour plot predicts insignificant interaction between variables. The point of intersection between major and minor axes gives the value of maximum point [31]. The amylase production varied significantly upon changing the levels of independent variables required for the growth of Bacillus sp. Response surface optimization of the independent variables led to enhance amylase production by 1.5-fold compared to the OFAT method. The findings proved that there was only $6.3 \%$ variation between experimental and predicted amylase production by RSM using BBD method at run order No. 1. Similarly, a significant increase in the amylase production from Bacillus sp. has been reported by statistical optimization tools [32,33].

The optimum values of the selected variables for maximum biomass were analyzed using the response surface contour plot. The ranges of variables for maximum biomass yield showed agreement with the range of variables responsible for the enhancement in amylase production by Bacillus sp. The RSM statistical approach using BBD resulted in two-fold enhancement of biomass yield from Bacillus sp. and suggested further that the optimized variables using BBD could be selected as the best condition for the development of a cost-effective approach in order to enhance amylase production in Bacillus sp. Thus, RSM could be a very powerful tool for enhancing enzyme production, by optimizing 
the various independent factors involved in the fermentation process with minimum number of experimental trials. The present study and previous reports suggest that this mathematical approach can be widely utilized for modeling operational variables (both dependent and independent) in order to maximize the yield of various responses (Table 5).

Table 5. Comparative assessment of amylase production from Bacillus sp.

\begin{tabular}{|c|c|c|c|c|c|c|}
\hline Organism & Method & Carbon Source & $\begin{array}{c}\text { Optimum pH } \\
\text { and Temperature }\end{array}$ & $\begin{array}{c}\text { Amylase Activity } \\
(\mathrm{U} / \mathrm{mL})\end{array}$ & Biomass & References \\
\hline Bacillus sp. & $\begin{array}{c}\text { BBD } \\
\text { (Box-Behnken } \\
\text { design) }\end{array}$ & Starch & $\begin{array}{l}\mathrm{pH}-6.0 \text {; } \\
\text { Temperature }-35^{\circ} \mathrm{C}\end{array}$ & 145.32 & $4.5 \mathrm{mg} / \mathrm{mL}$ & Present study \\
\hline B. brevis & $\begin{array}{c}\mathrm{CCD}(\text { Central } \\
\text { composite design) }\end{array}$ & Cassava baggase & $\begin{array}{l}\mathrm{pH}-7.0 \text {; } \\
\text { Temperature }-60^{\circ} \mathrm{C}\end{array}$ & 4667 & ND & [34] \\
\hline B. amyloliquefaciens & Non-statistical & $\begin{array}{l}\text { Potato starchy } \\
\text { waste }\end{array}$ & $\begin{array}{l}\mathrm{pH}-7.0 \text {; } \\
\text { Temperature }-50^{\circ} \mathrm{C}\end{array}$ & 155.2 & $0.51 \mathrm{~g} / \mathrm{L}$ & [5] \\
\hline B. licheniformis & OFAT and PBD & Starch & $\begin{array}{l}\mathrm{pH}-7.0 \\
\text { Temperature }-40^{\circ} \mathrm{C}\end{array}$ & 13.44 & ND & [35] \\
\hline Bacillus sp. & Non-statistical & Starch & $\begin{array}{l}\mathrm{pH}-6.0 \\
\text { Temperature }-55^{\circ} \mathrm{C}\end{array}$ & 760 & ND & [36] \\
\hline B. amyloliquefaciens & Non-statistical & Corn flour & $\begin{array}{l}\mathrm{pH}-9.0 \\
\text { Temperature }-42{ }^{\circ} \mathrm{C}\end{array}$ & 54.93 & ND & [27] \\
\hline B. subtilis & $\mathrm{CCD}$ & Starch & $\begin{array}{l}\mathrm{pH}-7.0 \text {; } \\
\text { Temperature }-37^{\circ} \mathrm{C}\end{array}$ & 639.7 & ND & [37] \\
\hline B. licheniformis & BBD & Starch & $\begin{array}{l}\mathrm{pH}-7.0 \text {; } \\
\text { Temperature }-45^{\circ} \mathrm{C}\end{array}$ & 384 & ND & [38] \\
\hline B. subtilis & Non-statistical & Rice flour & $\begin{array}{l}\mathrm{pH}-8.0 ; \\
\text { Temperature }-37^{\circ} \mathrm{C}\end{array}$ & 9 & ND & [4] \\
\hline B. amyloliquefaciens & CCD & Wheat bran & $\begin{array}{l}\mathrm{pH}-8.0 \text {; } \\
\text { Temperature }-65^{\circ} \mathrm{C}\end{array}$ & 63.12 & ND & [30] \\
\hline B. amyloliquefaciens & $\mathrm{CCD}$ & Rice starch & $\begin{array}{l}\mathrm{pH}-5.0 \\
\text { Temperature }-37^{\circ} \mathrm{C}\end{array}$ & 225 & ND & [39] \\
\hline B. subtilis & Non-statistical & Starch & $\begin{array}{l}\mathrm{pH}-8.0 ; \\
\text { Temperature }-37^{\circ} \mathrm{C}\end{array}$ & $1.32 \mathrm{U} / \mathrm{mg}$ & ND & [40] \\
\hline Bacillus sp. & $2^{4}$ factorial & Starch & $\begin{array}{l}\mathrm{pH}-6.2 ; \\
\text { Temperature }-37^{\circ} \mathrm{C}\end{array}$ & 17.54 & ND & [41] \\
\hline B. subtilis & Non-statistical & Wheat bran & $\begin{array}{l}\mathrm{pH}-7.0 \\
\text { Temperature }-42{ }^{\circ} \mathrm{C}\end{array}$ & 1918 & $\mathrm{ND}$ & [42] \\
\hline B. sonorensis & $\mathrm{CCD}$ & Starch & $\begin{array}{l}\mathrm{pH}-9.5 ; \\
\text { Temperature }-50^{\circ} \mathrm{C}\end{array}$ & 82.78 & ND & [43] \\
\hline B. tequilensis & Non-statistical & Starch & $\begin{array}{l}\mathrm{pH}-7.0 \text {; } \\
\text { Temperature }-55^{\circ} \mathrm{C}\end{array}$ & 8100 & ND & [44] \\
\hline B. subtilis & Non-statistical & Starch & $\begin{array}{l}\mathrm{pH}-6.0 \text {; } \\
\text { Temperature }-35^{\circ} \mathrm{C}\end{array}$ & 150.32 & $2.7 \mathrm{mg} / \mathrm{mL}$ & [45] \\
\hline
\end{tabular}

ND—Not Determined.

In the current scenario, a large number of microorganism-derived amylases are available commercially on the market. These amylases are known for the replacement of chemical processes involved in starch hydrolysis. In spite of this, the applications of these enzymes are restricted due to their limited stability to extreme temperature and $\mathrm{pH}$. In the present study, amylase obtained from Bacillus sp. was found to be not only thermo-stable, but also alkali-tolerant for a longer period. The amylases obtained from Bacillus sp. could be a better substitute for the existing enzymes on the market as they can be used in harsh industrial processes for commercialization. In fact, the thermo-stable characteristics of the present isolate provides superiority to the currently available amylases on the market due to the decreased risk of contamination and costs of the external cooling process. The high productivity over a shorter period and the long-term alkali-tolerant property of amylases obtained from Bacillus sp. could not only be utilized for vast commercialization but also for the conversion of a broadly varied starch feedstock in a cost-effective manner. 


\section{Conclusions}

In the present study, Bacillus sp. from poultry source had been identified as potent producer of amylase with efficient yield in submerged fermentation process. The production of amylase was increased in shorter time interval by response surface methodology (RSM) using the Box-Behnken design (BBD). BBD established 1.5-fold and 2-fold enhancements in the amylase production and biomass yield respectively compared to non-optimized conditions by interacting with four different influencing variables: $\mathrm{pH}$, temperature, agitation speed and incubation period. The crude enzyme showed stability at a wide range of temperature and $\mathrm{pH}$ with $51 \%$ and $66.13 \%$ of relative activity, respectively, indicating broad spectrum application of thermo-alkali-tolerant amylase in various industries. The designed model based upon the multi-variable analysis provides the strategy to produce amylase at a large scale from this strain. Further study is in progress to scale up enzyme production in a batch fermenter using BBD-optimized conditions.

Acknowledgments: This study was partially supported by Maulana Azad National Fellowship (F1-17.1/201516/MANF-2015-17-BIH-60730), University Grants Commission, Delhi, India.

Author Contributions: Ameer Khusro, Kaliyan Barathikannan and Chirom Aarti performed the experiments; Ameer Khusro and Chirom Aarti wrote the manuscript; Paul Agastian analyzed and verified the data.

Conflicts of Interest: The authors declare no conflict of interest.

\section{References}

1. Adrio, J.L.; Demain, A.L. Microbial enzymes: Tools for biotechnological processes. Biomolecules 2014, 4, 117-139. [CrossRef] [PubMed]

2. Souza, P.M.; Magalhaes, P.O. Application of microbial $\alpha$-amylase in industry-A review. Braz. J. Microbiol. 2010, 41, 850-861. [PubMed]

3. John Ravindar, J.D.; Elangovan, N. Molecular identification of amylase producing Bacillus subtilis and detection of optimal conditions. J. Pharm. Res. 2013, 6, 426-430. [CrossRef]

4. Dash, B.K.; Rahman, M.M.; Sarker, P.K. Molecular identification of a newly isolated Bacillus subtilis BI19 and optimization of production conditions for enhanced production of extracellular amylase. BioMed Res. Int. 2015, 2015, 859805. [CrossRef] [PubMed]

5. Abd-Elhalem, B.T.; El-Sawy, M.; Gamal, R.F.; Abou-Taleb, K.A. Production of amylases from Bacillus amyloliquefaciens under submerged fermentation using some agro-industrial by-products. Ann. Agric. Sci. 2015, 60, 193-202. [CrossRef]

6. Elibol, M. Optimization of medium composition for actinorhodin production by Streptomyces coelicolor A3(2) with response surface methodology. Process Biochem. 2004, 39, 1057-1062. [CrossRef]

7. Khusro, A.; Barathikannan, K.; Al-Dhabi, N.A.; Arasu, M.V.; Agastian, P. Statistical optimization of thermo-alkali stable xylanase production from Bacillus tequilensis strain ARMATI. Electron. J. Biotechnol. 2016, 22, 16-25. [CrossRef]

8. Pandey, A.; Nigam, P.; Soccol, C.R.; Soccol, V.; Singh, D.; Mohan, R. Advances in microbial amylases. Biotechnol. Appl. Biochem. 2000, 31, 135-152. [CrossRef] [PubMed]

9. Haq, I.; Ashraf, H.; Iqbal, J. Production of $\alpha$-amylase by Bacillus licheniformis using an economical medium. Bioresour. Technol. 2003, 87, 57-61.

10. Sneath, P.H.A. Gram positive rods. In Bergeys Manual of Systematic Bacteriology, 9th ed.; Hensyl, W.M., Ed.; Williams and Wilkins: Philadelphia, PA, USA, 1994; pp. 2106-2111.

11. Miller, G.L. Use of dinitrosalisylic acid reagent for determination of reducing sugar. Anal. Chem. 1959, 31, 426-428. [CrossRef]

12. Samanta, A.; Mitra, D.; Roy, S.N.; Sinha, C.; Pal, P. Characterization and optimization of amylase producing bacteria isolated from solid waste. J. Environ. Prot. 2013, 4, 647-652. [CrossRef]

13. Karataş, H.; Uyar, F.; Tolan, V.; Baysal, Z. Optimization and enhanced production of $\alpha$-amylase and protease by a newly isolated Bacillus licheniformis ZB-05 under solid state fermentation. Ann. Microbiol. 2013, 63, 45-52. [CrossRef] 
14. Kumarai, B.L.; SaiRam, C.V.S.; Kumar, T.S.; Sudhakar, P.; Vijetha, P. Screening and isolation of thermostable $\alpha$-amylase producing bacteria and optimization of physico-chemical parameters for increasing the yield. Int. J. Pharm. Technol. 2011, 3, 1570-1583.

15. Kamm, B.; Kamm, M. Biorefinery-Systems. Chem. Biochem. Eng. 2004, 18, 1-6.

16. Choubane, S.; Khelil, O.; Cheba, B.A. Bacillus sp. $\mathrm{R}_{2} \alpha$-amylase production optimization: Pasta cooking water as medium of amylase production. Afr. J. Biotechnol. 2015, 14, 3184-3189.

17. Salman, T.; Kamal, M.; Ahmed, M.; Siddiqa, S.M.; Khan, R.A.; Hassan, A. Medium optimization for the production of amylase by Bacillus subtilis RM16 in shake-flask fermentation. Pak. J. Pharm. Sci. 2016, 29, 439-444. [PubMed]

18. Bozic, N.; Ruiz, J.; Lopez-Santin, J.; Vujcic, Z. Optimization of the growth and $\alpha$-amylase production of Bacillus subtilis IP 5832 in shake flask and laboratory fermenter batch cultures. J. Serb. Chem. Soc. 2011, 76, 965-972. [CrossRef]

19. Nusrat, A.; Rahman, S.R. Comparative studies on the production of extracellular $\alpha$-amylase by three mesophilic Bacillus isolates. Bangladesh J. Microbiol. 2007, 24, 129-132. [CrossRef]

20. Asgher, M.; Javaidasad, M.; Rahman, S.U.; Legge, R.L. A thermostable $\alpha$-amylase from a moderately thermophilic Bacillus subtilis strain for starch processing. J. Food Eng. 2007, 79, 950-955. [CrossRef]

21. Willey, J.M.; Sherwood, L.M.; Woolverton, C.J. Prescott, Harley and Klein's Microbiology; McGraw-Hill: Singapore, 2008; p. 1088.

22. Saxena, R.K.; Dutt, K.; Agarwal, L.; Nayyar, P. A highly thermo stable and alkaline amylase from a Bacillus sp. PN5. Bioresour. Technol. 2007, 98, 260-265. [CrossRef] [PubMed]

23. Raul, D.; Biswas, T.; Mukhopadhyay, S.; Das, S.K.; Gupta, S. Production and partial purification of $\alpha$ amylase from Bacillus subtilis (MTCC 121) using solid state fermentation. Biochem. Res. Int. 2014, 2014, 568141. [CrossRef] [PubMed]

24. Vijayalakshmi, A.; Sushma, K.; Abha, S.; Chander, P. Isolation and characterization of Bacillus subtilis KC3 for amylolytic activity. Int. J. Biosci. Biochem. Bioinform. 2012, 2, 336-341. [CrossRef]

25. Guleria, A.; Chatanta, D.K. Isolation, screening and optimization of microorganism producing amylase. Glob. J. Res. Anal. 2014, 3, 3-181.

26. Sharma, K.; Bhutty, S.; Paul Khurana, S.M.; Kohli, U.K. Isolation, identification and optimization of culture conditions of Bacillus sp. strain PM1 for alkalo-thermostable amylase production. Br. Microbiol. Res. J. 2014, 4, 369-380. [CrossRef]

27. Deb, P.; Talukdar, S.A.; Mohsina, K.; Sarker, P.K.; Abu Sayem, S.M. Production and partial characterization of extracellular amylase enzyme from Bacillus amyloliquefaciens P-001. SpringerPlus 2013, 2, 154. [CrossRef] [PubMed]

28. Hakulinen, N.; Turunen, O.; Janis, J.; Leisola, M.; Rouvinen, J. Three-dimensional structures of thermophilic $\beta-1,4$-xylanases from Chaetomium thermophilum and Nonomuraea flexuosa comparison of twelve xylanases in relation to their thermal stability. Eur. J. Biochem. 2003, 270, 1399-1412. [CrossRef] [PubMed]

29. Zhao, W.; Zheng, J.; Wang, Y.G.; Zhou, H. A marked enhancement in production of amylase by Bacillus amyloliquefaciens in flask fermentation using statistical methods. J. Cent. South Univ. Technol. 2011, 18, 1054-1062. [CrossRef]

30. Prajapati, V.S.; Trivedi, U.B.; Patel, K.C. A statistical approach for the production of thermostable and alklophilic $\alpha$-amylase from Bacillus amyloliquefaciens KCP2 under solid-state fermentation. 3 Biotech 2015, 5, 211-220. [CrossRef]

31. Muralidhar, R.V.; Chirumamila, R.R.; Marchant, R.; Nigam, P. A response surface approach for the comparison of lipase production by Candida cylindracea using two different carbon sources. Biochem. Eng. J. 2001, 9, 17-23. [CrossRef]

32. Gangadharan, D.; Sivaramakrishnan, S.; Nampoothiri, K.M.; Sukumaran, R.K.; Pandey, A. Response surface methodology for the optimization of $\alpha$ amylase production by Bacillus amyloliquefaciens. Bioresour. Technol. 2008, 99, 4597-4602. [CrossRef] [PubMed]

33. Kiran, K.K.; Chandra, T.S. Production of surfactant and detergent-stable, halophilic and alkalitolerant $\alpha$-amylase by a moderate halophilic Bacillus sp. strain TSCVKK. Appl. Microbiol. Biotechnol. 2008, 77, 1023-1031. [CrossRef] [PubMed]

34. Ray, R.C.; Kar, S. Statistical optimization of $\alpha$-amylase production by Bacillus brevis MTCC 7521 in solid-state fermentation using cassava bagasse. Biologia 2009, 64, 864-870. [CrossRef] 
35. Abel-Nabey, H.M.; Farag, A.M. Production, optimization and characterization of extracellular amylase from halophilic Bacillus lichineformis AH214. Afr. J. Biotechnol. 2016, 15, 670-683.

36. Paul, J.S.; Lall, B.M.; Jadhav, S.K.; Tiwari, K.L. Parameter's optimization and kinetics study of $\alpha$-amylase enzyme of Bacillus sp. MB6 isolated from vegetable waste. Process Biochem. 2017, 52, 123-129. [CrossRef]

37. Sumrin, A.; Ahmad, W.; Ijaz, B.; Sarwar, M.T.; Gull, S.; Kausar, H.; Shahid, I.; Jahan, S.; Asad, S.; Hussain, M. Purification and medium optimization of $\alpha$-amylase from Bacillus subtilis168. Afr. J. Biotechnol. 2011, 10, 2119-2129.

38. Abdel-Fattah, Y.R.; Soliman, N.A.; El-Toukhy, N.M.; El-Gendi, H.; Ahmed, R.S. Production, purification, and characterization of thermostable $\alpha$-amylase produced by Bacillus licheniformis isolate AI20. J. Chem. 2013, 2013, 673173. [CrossRef]

39. Samadlouie, H.; Karimiroozbahani, M.; Kaboosi, H.; Farrokhi, N. Optimizations of $\alpha$-amylase production by response surface methodology in immobilization Bacillus amyloliquefaciens ATCC 23350. Biol. J. Microorg. 2016, 4, 77-86.

40. Punia, P.; Kaushik, S.; Jyoti, A. Optimization of production conditions and partial characterization of extracellular amylase from Bacillus subtilis under submerged condition. J. Sci. Ind. Res. 2016, 75, 371-377.

41. Tanyildizi, M.S.; Ozer, D.; Elibol, M. Optimization of $\alpha$-amylase production by Bacillus sp. using response surface methodology. Process Biochem. 2005, 40, 2291-2296. [CrossRef]

42. Maity, S.; Mallik, S.; Basuthakur, R.; Gupta, S. Optimization of solid state fermentation conditions and characterization of thermostable $\alpha$-amylase from Bacillus subtilis (ATCC 6633). J. Bioprocess. Biotech. 2015, 5, 4.

43. Vyas, G.; Sharma, N. Production and optimization of $\alpha$-amylase from a novel thermoalkalophilic Bacillus sonorensis GV2 isolated from mushroom compost. Proc. Indian Natl. Sci. Acad. 2015, 81, 1207-1221. [CrossRef]

44. Tiwari, S.; Shukla, N.; Mishra, P.; Rajeeva Gaur, R. Enhanced production and characterization of a solvent stable amylase from solvent tolerant Bacillus tequilensis RG-01: Thermostable and surfactant resistant. Sci. World J. 2014, 2014, 972763. [CrossRef] [PubMed]

45. Khusro, A.; Aarti, C. Molecular identification of newly isolated Bacillus strains from poultry farm and optimization of process parameters for enhanced production of extracellular amylase using OFAT method. Res. J. Microbiol. 2015, 10, 393-420. [CrossRef]

(C) 2017 by the authors; licensee MDPI, Basel, Switzerland. This article is an open access article distributed under the terms and conditions of the Creative Commons Attribution (CC BY) license (http:/ / creativecommons.org/licenses/by/4.0/). 